\title{
Eclectic/mixed approach to physiotherapy in post-stroke patients - case study
}

\section{Eklektyczne lub mieszane podejście w fizjoterapii pacjentów po udarze - opis przypadku}

\author{
Emilia Mikołajewska ${ }^{1,2,3}$ \\ ${ }^{1}$ Chair of Physiotherapy, Ludwik Rydygier Collegium Medicum in Bydgoszcz, Nicolaus Copernicus University in Torun, Poland \\ Head of the Chair: Prof. Aleksander Goch PhD \\ ${ }^{2}$ Rehabilitation Clinic, $10^{\text {th }}$ Military Clinical Hospital with Polyclinic, Bydgoszcz, Poland \\ Head of the Clinic: Krzysztof Radziszewski MD \\ ${ }^{3}$ Neurocognitive Laboratory, Interdiscipinary Centre for Modern Technologies, Nicolaus Copernicus University in Torun, Poland \\ Head of the Laboratory: Prof. Włodzisław Duch PhD
}

Key words: physiotherapy, stroke, neurorehabilitation, eclectic approach to intervention, mixed approach.

Słowa kluczowe: fizjoterapia, udar, neurorehabilitacja, podejście eklektyczne, podejście mieszane.

\begin{abstract}
The prevalence of stroke, and its associated costs, are going to rise with the aging population and changes in lifestyle in developing countries. Further research should better identify modifiable and non-modifiable determinants of poor outcomes in stroke survivors. Complex rehabilitation of post-stroke survivors still needs novel solutions. An eclectic/mixed approach to intervention, regarded as synthesis of the classical intervention methods, techniques, and tools, may be regarded as one of them, but it still needs more research. The aim of the article is to familiarise the aforementioned approach based on the presented case report and to investigate the extent to which available opportunities of an eclectic/mixed approach to physiotherapy is being exploited.
\end{abstract}

\section{Streszczenie}

Zachorowalność na udary i związane z tym koszty rosną wraz ze starzeniem się populacji oraz zmianą trybu życia w krajach rozwiniętych. Dalsze badania powinny lepiej zidentyfikować modyfikowalne i niemodyfikowalne czynniki decydujące o słabych wynikach u chorych po udarach. Kompleksowa rehabilitacja tej grupy pacjentów ciągle wymaga nowych rozwiązań. Jednym z nich jest podejście eklektyczne lub mieszane, uznawane za syntezę tradycyjnych metod, technik i narzędzi, lecz ciągle wymaga ono wielu badań. Celem pracy jest przybliżenie omawianego podejścia na podstawie przedstawionego opisu przypadku, a także ocena, na ile obecne możliwości w tym zakresie są wykorzystywane w codziennej praktyce klinicznej.

\section{Introduction}

Despite stroke being regarded as the fourth cause of mortality and the leading cause of disability in the adult population in the United States, the worldwide negative impact of stroke may be even more serious [1-3]. Stroke epidemiology in the adult population is as follows:

1) as stroke risk factors are regarded:

- modifiable risk factors (in approx. 90\% of ischaemic and intracerebral haemorrhagic stroke cases in the study): hypertension, diabetes, cardiac causes, smoking, alcohol, obesity, hyperlipidaemia, diet, physical inactivity, psychosocial stress, and depression [4],
- non-modifiable risk factors: age (> 55 y.o.), race/ ethnicity (higher among African Americans, Hispanics, Chinese), sex (risk 24-30\% higher in men, although women live longer), first-degree relatives to ischaemic stroke victims, geography (e.g. the socalled "stroke belt" in the U.S.) [1],

2) in the U.S.: $3 \%$ of the adult population (approx. 7 million patients), including $87 \%$ are ischaemic infarctions $(87 \%)$, primary haemorrhages $(10 \%)$, and subarachnoid haemorrhages (3\%) - overall worldwide estimates vary widely [5],

3) incidence of stroke increases with age: from $30-120 / 100,000$ citizens (35-44 y.o.) per year to 670970/100,000 citizens (65-74 y.o.) per year - it seems 
that the current incidence of stroke in developed (high-income) countries has diminished thanks to better risk factors control and higher life expectancy, but will rise due to the aging of the population [1],

4) percentage of primary haemorrhages among all strokes: $10-17 \%$ in Western countries, approx. $25 \%$ in Asian countries [5], with frequency of primary haemorrhage lower in persons of European origin, and higher in individuals of African, Asian, and Latin American origin [6],

5) general mortality in the U.S. in 2006: 47\% [1], but highest mortality rates may be observed in Eastern Europe, North Asia, Central Africa, and the South Pacific [1],

6) as factors influencing general dependence and therapy (including neurorehabilitation) outcomes in stroke-survivors are regarded:

- outcomes in admission,

- age: 3 months after stroke older patients stay longer in hospital, and were more disabled and severely handicapped [7],

- socioeconomic status,

- race/ethnicity,

- gender: predictions are less favourable in women,

- geography.

It seems that the prevalence of stroke and associated costs are going to rise with the aging population (in developed countries) and changes in lifestyle (in developing countries). Undoubtedly, further research should better identify modifiable and non-modifiable determinants of poor outcomes in stroke survivors. Moreover, the aforementioned situation may change with advances in medical science (including acute stroke care, neurology, neurosurgery, neurorehabilitation, and secondary stroke prevention), advances in medical technology and assistive technology, and worldwide and local societal and economical changes.

The eclectic/mixed approach is regarded as a synthesis of classical intervention methods, techniques, and tools [8]. Despite the fact that it is not a purely innovative idea of therapy, it still requires the design and evaluation of experimental research studies of its efficacy. It seems that the eclectic/mixed approach has been unconsciously, intuitively used by experienced therapists but has not been properly defined previously. It not only stimulates change and advancement, but also allows for flexible transition from a traditional approach to a patient-tailored therapy. Advanced clinical practice requires the use of an individual and problem-solving approach and advanced skills in the therapy of patients with complex dysfunctions. Based on diagnosis there is a need to formulate the treatment plan consisting of the most effective combination of available (and acceptable in the current patient's health status) procedures, methods, techniques, and tools. An evidence-based decision-making process may be difficult due to evidence allowing for the most effective combination choice.
This study aims to familiarise the aforementioned approach based on the presented case report and to investigate the extent to which available opportunities of an eclectic/mixed approach to physiotherapy are being exploited.

\section{Functional results of stroke}

There may be a close connection between cognitive and functional deficits in post-stroke patients. Poor cognitive outcomes, particularly in executive functions, may be a predictor of poor recovery after stroke. But we should be aware that cognitive impairments may be observed in up to $78 \%$ of poststroke patient in the post-acute phase [9], and they may be perceived, particularly in ischaemic stroke, as predictors of poor long-term survival. Among the cognitive deficits seen in post-stroke survivors in the post-acute phase the most frequent are: attention disorders $(48.5 \%)$ - still the most frequent at 1-year follow-up, language disorders (27\%), short-term memory disorders (24.5\%), executive function disorders $(18.5 \%)$ [9].

Executive dysfunction, aphasia, and long-term memory disorders were the least frequent at 1-year follow-up [9].

General dependence of stroke survivors 6 months after stroke were observed as follows: $30 \%$ were unable to ambulate without assistance, $26 \%$ were dependent in activities of daily living (ADLs) [5].

High variability of functional deficits in patients after stroke makes therapy in these cases among the most difficult. The general goals of post-stroke rehabilitation are complication management and restitution of function. Most of the patients need gait re-education and rehabilitation due to upper limb paresis (as many as $80 \%$ ) [10].

\section{Case study of eclectic/mixed therapy in a post-stroke survivor}

\section{Materials}

Women (57 y.o.), 1 month after ischaemic stroke (left side of the brain), right hemiparesis, was admitted to the Posttraumatic Paraplegia Ward of the Clinical Military Hospital No. 10 in Bydgoszcz in January 2014. As a result of functional assessment, her functional abilities at admission were as follows: patient could sit without support in a wheelchair and could move in a wheelchair.

\section{Goals of the therapy}

- Long-term goals: recovery of gait function, recovery of upper limb function.

- Short-term goals: reinforcement of trunk muscles, reinforcement of right lower limb muscles, reinforcement of right upper limb muscles. 
- Elementary goals: muscle tone normalisation, improvement of sensation in the upper limb, improvement of sensation in the lower limb, adaptation to vertical position.

\section{Methods}

Eclectic/mixed therapy was implemented in the described case, where available -5 days a week. Elements of the eclectic approach to intervention were as follows:

1) elements of the Bobath Concept (method);

2) elements of the kinesiotherapy:

- supported exercises,

- active exercises (without load),

- active exercises (with load),

- exercises using body-weight support systems,

- exercises using body-weight support systems with resistance;

3) vertical posture re-education;

4) gait re-education;

5) massage (dry);

6) kinesiology taping (method);

7) traditional physiotherapy techniques;

8) elements of hydrotherapy.

The kinds of exercises, numbers of repetition, and level of the load changed with the recovery of muscle strength. The features of the traditional physiotherapy techniques changed with the recovery of the patient (Table 1).

Various measures were introduced to assess changes in functional abilities as a result of the therapy. Functional abilities were assessed using our own scale (Table 2) since there is a lack of such wide clinical scores and scales. Strength of the muscles was assessed using the Lovett scale. The results of the therapy were assessed according the rule: recovery or lack of recovery. Such a global approach to the assessment of functional abilities recovery caused a lack of application of the more detailed scores and scales such as the Ashworth Scale for Grading Spasticity.

\section{Results}

After 2 months of the aforementioned eclectic therapy the patient achieved functional recovery (or) in 27 out of 33 assessed abilities, including inter alia: independent active standing, ADLs abilities (independent: dressing and stripping, toilet, washroom, eating, moving inside and outside), independent walking.

Abilities 1, 2, 3, 27, and 28 were assessed as existing before the therapy, and did not change during the therapy. Only one ability was not achieved: car driving.

\section{Discussion}

Changes in the lifestyle and life quality of strokesurvivors significantly influence their everyday func- tioning. The aforementioned changes depend on the kind, extent, and location of changes within the nervous system. Due to problems with cognitive functions and voluntary movements, the common (with the patient and his/her family/caregivers) patient-oriented goal-setting can be very important. The most frequent preferences of patients are walking and upper limb function. Thus the most important tasks of the therapist may be perceived as follows: prevention of pathological secondary changes, recovery to walking, recovery to upper limb(s) function.

Functional recovery should be associated with avoiding compensation. Compensations always generate other abnormalities; moreover, extensive effort during movement tasks may cause an increase in muscle tone and decrease the chance of recovery of normal upper limb and lower limb function. Thus the therapist should pay particular attention to the coincidence of tasks and conditions, to fulfil them without pathological elements. Overly rapid transition to the next task may demotivate and (paradoxically) extend the time of rehabilitation.

The eclectic/mixed approach needs a higher level of clinical reasoning and professional development in physiotherapy. I have observed a positive attitude - many physical therapists are convinced of the advantages of the use of an eclectic/mixed approach to intervention.

There is a lack of strict standards and clinical guidelines concerning rehabilitation (especially physiotherapy) in post-stroke survivors, despite the fact that the mixed approach to intervention is the suggested means of operation. Each therapist wants to apply the most effective set of therapeutic methods, but there is a need for more research on the efficiency of a mixed approach, especially more detailed randomised, controlled trials engaging larger groups of patients. The main facilitators for the implementation of the aforementioned eclectic/mixed approach in post-stroke rehabilitation includes physical therapists' competence, practice organisation, and the availability and feasibility of a known approach to intervention (a core set of therapeutic methods). The main barriers can constitute lack of knowledge and not focusing on the patient's goals and best available outcomes of the therapy as far as organisational factors are concerned: lack of time, room, management support.

The main limitation is caused by the case study itself, but based on the solutions and factors identified herein, an increased number of therapeutic strategies can be developed and evaluated in future research.

\section{Conclusions}

There is a lack of similar case studies to compare with that described above. Many contemporary case studies describing simultaneous use of various methods and techniques may unconsciously prove the effi- 


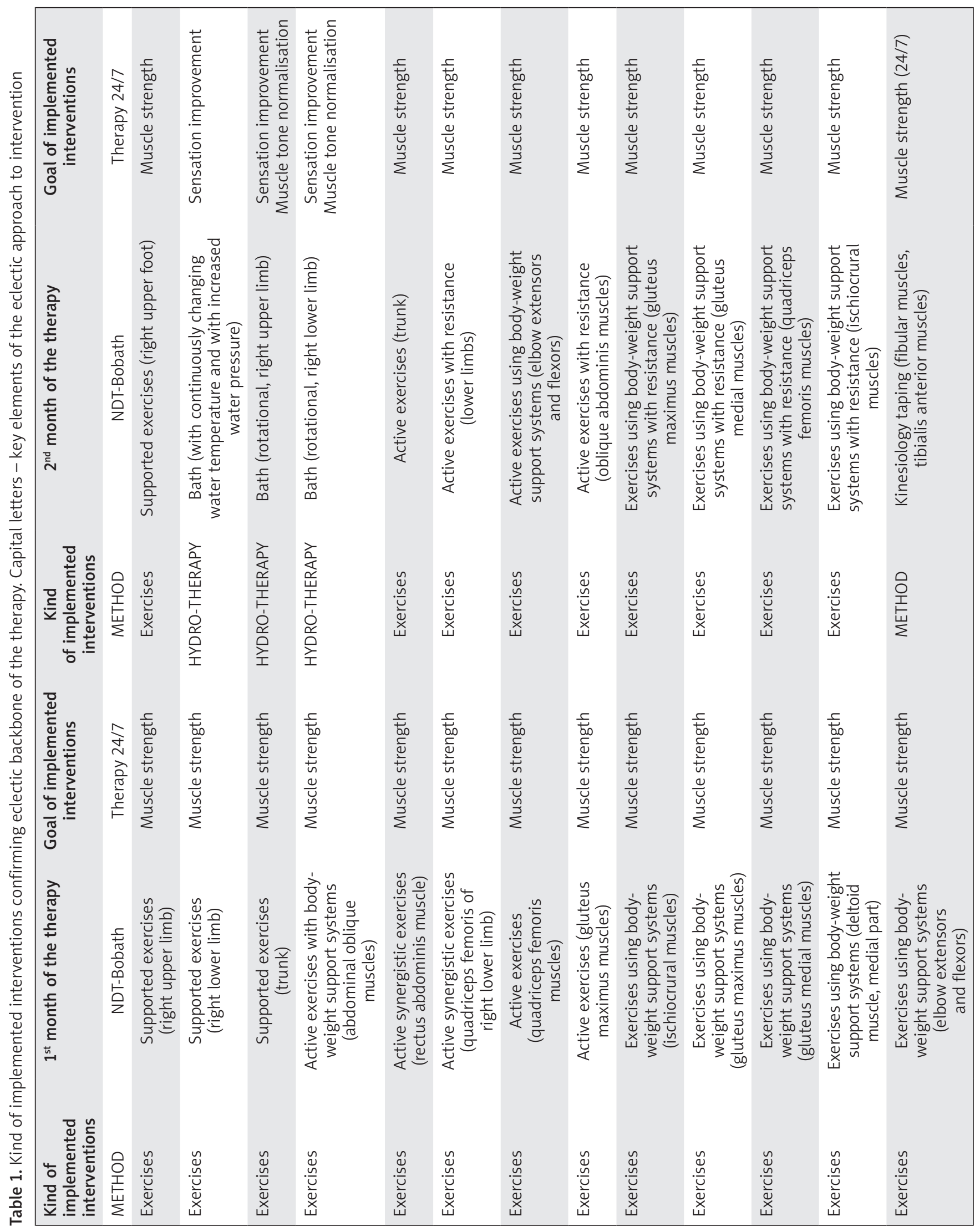




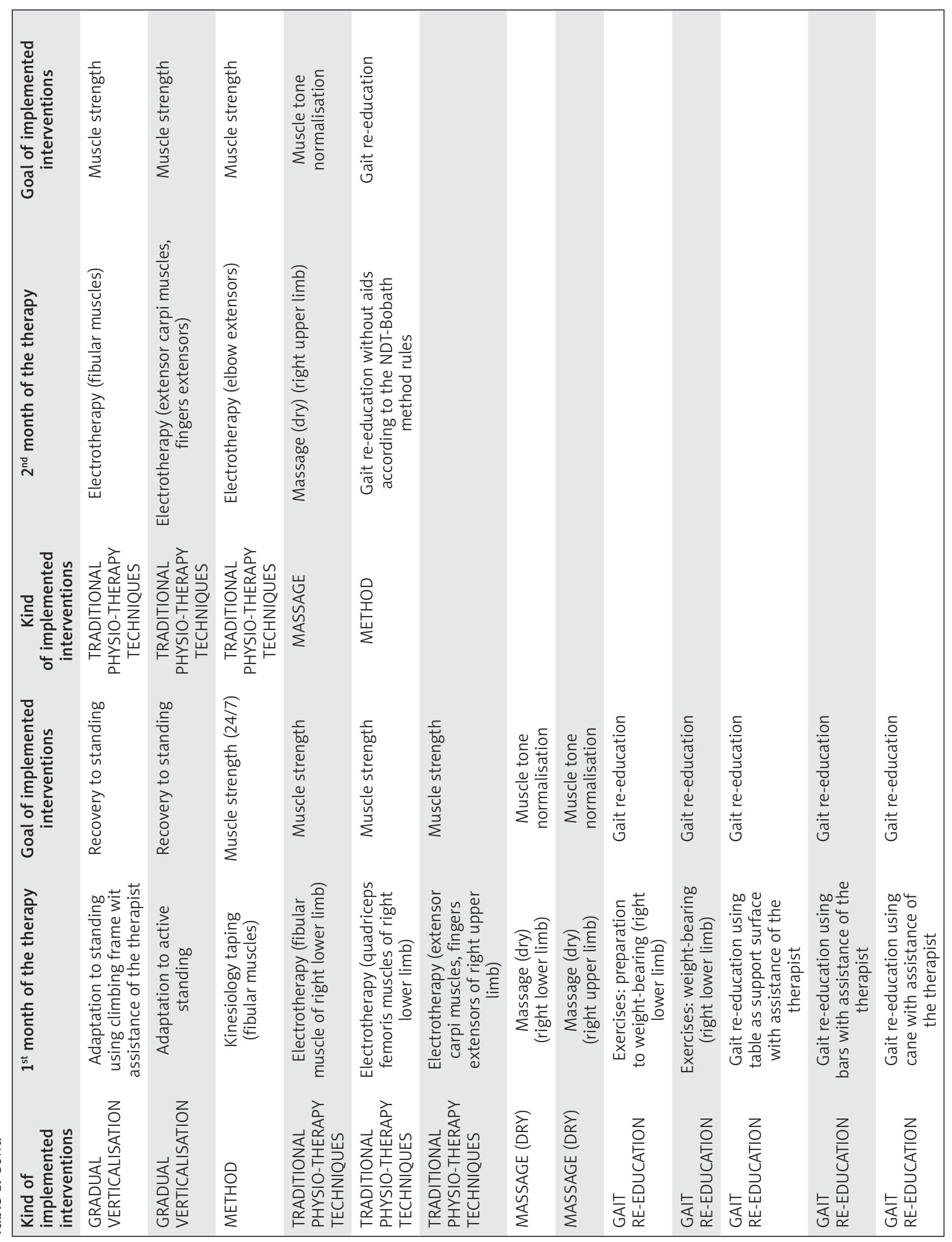


Table 2. Abilities achieved by the patient as a result of eclectic therapy

\begin{tabular}{|c|c|c|c|}
\hline No. & Ability & Before therapy & After 2 months of eclectic therapy \\
\hline 1 & Transfer from lying to sitting & + & + \\
\hline 2 & Sitting with support & + & + \\
\hline 3 & Sitting without support & + & + \\
\hline 4 & Standing: passive & - & + \\
\hline 5 & Standing: active-passive & - & + \\
\hline 6 & Standing: active & - & + \\
\hline 7 & Strength of rectus abdominis muscles* & $3+$ & 5 \\
\hline 8 & Strength of oblique abdominis muscles* & $2+$ & 5 \\
\hline 9 & Strength of gluteus maximus muscles* & $2+$ & 5 \\
\hline 10 & Strength of gluteus medius muscles* & $2+$ & 5 \\
\hline 11 & Strength of erector spinae muscle* & $3-$ & 5 \\
\hline 12 & Strength of latissimus dorsi muscle* & $2+$ & 5 \\
\hline 13 & Strength of ischiocrural muscles* & $2+$ & 3 \\
\hline 14 & Strength of quadriceps femoris muscles* & $3-$ & 4 \\
\hline 15 & Strength of plantar flexor of foot* & 1 & $3+$ \\
\hline 16 & Strength of elbow flexors* & 2 & $3+$ \\
\hline 17 & Strength of triceps brachii muscles* & 2 & $3+$ \\
\hline 18 & Strength of deltoid muscles* & 2 & $4-$ \\
\hline 19 & Strength of extensor muscles of wrist* & 2 & $3+$ \\
\hline 20 & Toilet & - & + \\
\hline 21 & Shower & - & + \\
\hline 22 & Dressing & - & + \\
\hline 23 & Rolling over from supine to prone (in bed) & - & + \\
\hline 24 & Transfer from bed to wheelchair & - & + \\
\hline 25 & Transfer from wheelchair to bed & - & + \\
\hline 26 & Adaptation to wheelchair & - & + \\
\hline 27 & Independent drinking & + & + \\
\hline 28 & Independent eating & + & + \\
\hline 29 & Inside activities (hospital, hall, home) & - & + \\
\hline 30 & Moving outside (pavement, street, etc.) & - & + \\
\hline 31 & Walking with aids & - & + \\
\hline 32 & Independent walking (without aids) & - & + \\
\hline 33 & Car driving & - & - \\
\hline
\end{tabular}

*Using Lovett scale.

cacy of the eclectic approach. Nevertheless, the eclectic approach stimulates the need for the development of new, advanced tools in the design and evaluation of experimental research studies. Moreover, advanced measurement theory and advanced methods of data analysis (data mining, computational neuroscience, artificial intelligence) will be useful as far as understanding qualitative data analysis is concerned.

\section{Conflict of interest}

The author declares no conflict of interest. 


\section{References}

1. Obviagele B, Nguyen-Huynh MN. Stroke epidemiology: Advancing our understanding of disease mechanism and therapy. Neurotherapeutics 2011; 8: 319-29.

2. Mukherjee D, Patil CG. Epidemiology and the global burden of stroke. World Neurosurg 2011; 76 (Suppl): S85-90.

3. Kuklina EV, Tong X, George MG, Bansil P. Epidemiology and prevention of stroke: a worldwide perspective. Expert Rev Neurother 2012; 12: 199-208.

4. O’Donnell MJ, Xavier D, Liu L, et al. Risk factors for ischaemic and intracerebral haemorrhagic stroke in 22 countries (The Interstroke Study): a case-control study. Lancet 2010; 376: 112-23.

5. Roger VL, Go AS, Lloyd-Jones DM, et al. Heart disease and stroke statistics - 2011 update: a report from the American Heart Association. Circulation 2011; 123: e18-209.

6. Ariesen MJ, Claus SP, Rinkel GJ, Algra A. Risk factors for intracerebral hemorrhage in the general population: a systematic review. Stroke 2003; 34: 2060-5.

7. di Carlo A, Lamassa M, Pracucci G, et al. Stroke in the very old: clinical presentation and determinants of 3-month functional outcome: a European perspective. European Biomed Study of Stroke Care Group. Stroke 1999; 30: 2313-9.

8. Mikołajewska E. Eclectic approach as the natural way of development in neurorehabilitation of adults. Int J Disabil Hum Develop 2013; 12: 373-8.

9. Leśniak M, Bąk T, Czepiel W, et al. Frequency and prognostic value of cognitive disorders in stroke patients. Dement Geriatr Cogn Disord 2008; 26: 356-63.

10. Knecht $S$, Hesse S, Oster P. Rehabilitation after stroke. Dtsch Arztebl Int 2011; 108: 600-6.

\section{Address for correspondence:}

Emilia Mikołajewska

Chair of Physiotherapy

Ludwik Rydygier Collegium Medicum in Bydgoszcz

Nicolaus Copernicus University in Torun

ul. M. Skłodowskiej-Curie 9, 85-094 Bydgoszcz, Poland

Phone: +48 607889909

E-mail: e.mikolajewska@wp.pl 